\title{
NEW DATA ON THE "SILVER-BELL CRICKET" (ORTHOPTERA, GRYLLIDAE), A FORGOTTEN AND OVERLOOKED CRICKET SUBJECT TO A HIGH RISK OF EXTINCTION IN WESTERN EUROPE
}

\author{
P. J. Cordero ${ }^{1 *} \&$ V. Llorente ${ }^{2}$
}

\begin{abstract}
Gryllodinus kerkennensis (Finot, 1893) presents a disjunct distribution in the Southern part of the Western Palearctic from North Africa up to Central Asia inhabiting arid, semidesert or desert land mostly associated with saline soils near water sources of lagoons or river beds depressions. The species was not recorded in Western Europe (Iberian Peninsula) since 1936 and up to now it is currently excluded from all red list books for Orthopteran conservation. In this paper we report a few and localised populations of this cricket in Castilla-La Mancha inhabiting sandy shores of hiper-saline lagoons. We also provide information on its biometrics, phenology, ecology and behaviour including data of all collection specimens of the Museo Nacional de Ciencias Naturales (MNCN). Because of its audible and particular song, we propose campaigns of night listening points to search for this species in other potential sites where it could be present. We believe that this species may be subject to a high risk of extinction in the Iberian Peninsula, and thus in the whole Western Europe. This is because of their restricted populations and the fragility of its specific habitat. We propose an urgent integral protection and the inclusion of the species in the lists of highly endangered invertebrate species.
\end{abstract}

Key words: Gryllodinus kerkennensis, disjunct distribution, Castilla-La Mancha, hipersaline lagoons, arid land, extinction risk.

\section{RESUMEN}

Nuevos datos sobre el "grillo cascabel de plata" (Orthoptera, Gryllidae), un grillo olvidado y sometido a un alto riesgo de extinción en Europa occidental

Gryllodinus kerkennensis (Finot, 1893) presenta una distribución disjunta a lo largo de la franja meridional y occidental del Paleártico, desde África del Norte hasta Asia Central, habitando zonas áridas, desiertos o semi-desiertos, principalmente asociado a suelos salinos próximos a masas de agua de lagunas o depresiones de cuencas fluviales. Esta especie no se registraba en Europa occidental (Península Ibérica) desde 1936 y en la actualidad está excluida de todas las listas de libros rojos para la conservación de Ortópteros. En este trabajo describimos varias poblaciones aisladas de este grillo en Castilla-La Mancha en orillas arenosas de lagunas hipersalinas. También proporciona-

Grupo de Investigación de la Diversidad Genética y Cultural, Instituto de Investigación en Recursos Cinegéticos-IREC (UCLM-CSIC-JCCLM). Ronda de Toledo s/n, 13005 Ciudad Real, España.

2 Museo Nacional de Ciencias Naturales. José Gutiérrez Abascal 2, 28006 Madrid, España

* Author for correspondence: pedrojavier.cordero@uclm.es 
mos información sobre su biometría, fenología, ecología y conducta incluyendo datos sobre la colección entera de especímenes depositados en el Museo Nacional de Ciencias Naturales (MNCN). Debido a su canto audible y muy particular, proponemos campañas de puntos nocturnos de escucha para rastrear la presencia de esta especie en otros posibles lugares donde aún pudiera estar presente. Creemos que esta especie pudiera estar en alto riesgo de extinción en la Península Ibérica, y por tanto en toda Europa Occidental debido a lo localizado de sus poblaciones y a la fragilidad de su hábitat específico. Por todo ello proponemos su protección integral y urgente debiéndose incluir en las listas de especies de invertebrados altamente amenazados.

\section{Introduction}

Gryllodinus kerkennensis (Finot, 1893)

Gryllodes kerkennensis Finot, 1893. Ann. Soc. Entomol. France, 62: 252.

Gryllodes macropterus Fuente, 1894. Actas Soc. Esp. Hist. Nat., 22: 137.

Gryllus pipiens (nec Dufuor) Saussure, 1874. In Fedtschenko, Voyage Turkestan, Orthopt., 31

Gryllodes lateralis (nec Fieber) Bonnet and Finot, 1885. Rev. Sci. Nat. Montpellier, 4: 363.

Gryllodes finoti Krauss, 1902. Verh. Kais.-K. Zool.-Bot. Ges. Wien, 52: 523.

Gryllodes dulcisonans Semenov, 1915. Rev. Russe Entomol., 15: 454.

Gryllodes (Gryllodinus) kerkennensis, Bolívar, 1927. Bol. R. Soc. Esp. Hist. Nat., 27: 103-104.

Eugryllodes macropterus, Chopard, 1927. Ann. Mag. Nat. Hist., (9), 19: 258.

This cricket was described from Algeria (Biskra) and the island of Kerkennah (Tunisia) (type specimens kept in the Natural History Museum of Paris) by Finot (1893) and almost simultaneously by Fuente (1894) (Gryllodes macropterus) from Pozuelo de Calatrava (Ciudad Real, Spain) whose type series is currently deposited in the Museo Nacional de Ciencias Naturales of Madrid (MNCN) (Gorochov \& Llorente, 2001).

Gryllodinus kerkennensis (from now on G.k) presents a disjunct Turano-Mediterranean distribution similar to other Orthopteran species like Mioscirtus wagneri (Kittary, 1859) or Tartarogryllus tartarus (Saussure, 1874) (Cordero et al., 2007a, b). It has been recorded from North Africa including Algeria, Tunisia (Finot, 1893), Western Sahara (MoralesAgacino, 1945, 1947; Fernandes, 1967) and Egypt (Uvarov, 1943; Fernandes, 1967); Central South Spain (Fuente, 1894; Fernandes, 1967); Cyprus (Fernandes, 1967); Near East including Syria (Uvarov, 1912), Iran and Iraq (Harz, 1969); Kuwait (Gorochov, 1993); SW Russia (Uvarov, 1912; Semenov, 1915) up to Central Asia in Turkmenistan (Uvarov, 1912; Semenov, 1915) and in Afghanistan
(Chopard, 1960). However, no consistent morphological variation has been published along this distribution to assign possible sub-speciation, although the number of specimens hitherto studied all around the world is not large and comparative studies on samples from different parts of the world are lacking.

The ample distribution of G.k could apparently reflect the wrong idea that the species is widespread and abundant. On the contrary, we believe that this is not the case, at least in the Iberian Peninsula. Up to now, the records of $G . k$ are sparse between the last decades of the nineteenth and beginnings of the twentieth centuries and are summarised by Gorochov \& Llorente (2001). The records are limited to those of Fuente (1894) in Pozuelo de Calatrava (Ciudad Real) and those mentioned by Fernandes (1967) from Quero (Toledo), Villacañas (Toledo) and Uclés (Cuenca). The last date in which G.k was captured/recorded in the Iberian Peninsula before the present study is June 1936 in Villacañas (Toledo) (Gorochov \& Llorente, 2001) (see also collection of the MNCN, Table 1). We believe that this lack of information is because the species is very rare or rather highly localised. This could be the reason why G.k has been a forgotten and overlooked species in terms of conservation as it is not present in any of the red list books of the Spanish Orthopteran fauna (Gangwere et al., 1985; Verdú \& Galante, 2005).

Descriptions of $G . k$ are found in Finot (1893), Fuente (1894), Bolívar (1894, 1898), Uvarov (1912), Bolívar (1927), Chopard (1943), Fernandes (1967) and Harz (1969). Fernandes (1967) and Gorochov (1979) also compared it with G. odicus. The genitalia was illustrated and described by Randell (1964), Fernandes (1967) and Gorochov (1979). Song was described by Semenov (1915) and oscilograms by Popov \& Shuvalov (1977).

In this paper we provide current information on the distribution, ecology and behaviour of this species in its fragile habitat. We propose an easy method to detect possible unknown populations, by 
using night sound recordings that may determine local present/absent status. We also provide body measures of own and museum collections in order to have a general picture of global size variation. Finally, we discuss the certainty of their current status, possible risks of imminent extinction and the need of urgent conservation of the few populations known of this species in the Iberian Peninsula (Western Europe).

\section{Material and methods}

\section{THE SPECIES}

The general colouration of $G . k$ is testaceous-pale with more or less brownish patterns (Fig. 1). Head is a bit wider than the anterior width of pronotum, with the front, vertex and the occipital region brown and a paler (yellowish) large transversal band. There is also a narrow, pale band between the eyes forming a pronounced angle and another line from the vertex backwards. Vertex is sloping, face arching forwards with the clypeo-frontalis suture clearly angular, almost reaching the anterior ocellus, surrounded with a brownish stripe. Transversal pronotum twice wider than long with two glowing brown spots on disc; anterior margin slightly concave, posterior one straight, lateral lobes relatively developed, more elevated at the anterior margin. Fore and middle legs short and light coloured; fore tibia only with tympanum on the outside, large and oval; postfemur relatively fragile, light coloured, with the outside more or less striped with light brown. Post-tibia almost 2/3 the length of the femur, a bit widened at the base, with the external and dorsal edge with 7-9 spines, the first ones small that may vanish reducing to 5; only 4-5 spines along the inner edge more frequently in the Spanish populations. Upper-inner spurs of the same length than the middle one and both are $1 / 3$ of the length of metatarsus which is denticulate at the edges. Male tegmen surpasses the extreme of the abdomen. The mirror is oval, one and a half times wider than long, divided in the middle by a slightly curved nerve but not forming an angle; two obliques. Apical field of tegmen large, sub-triangular with rounded apex presenting a regular reticulation. Lateral field large and almost transparent. The sub-cubital vein presents three unconnected branches. Female tegmen surpasses the fifth abdominal tergum, longer in "macropterous" forms, almost transparent, testaceous with slightly irregular large reticulation (Fernandes, 1967). Wings are long ("alae caudatae") in macropterous forms, the tegmina being as long as the abdomen in both males and

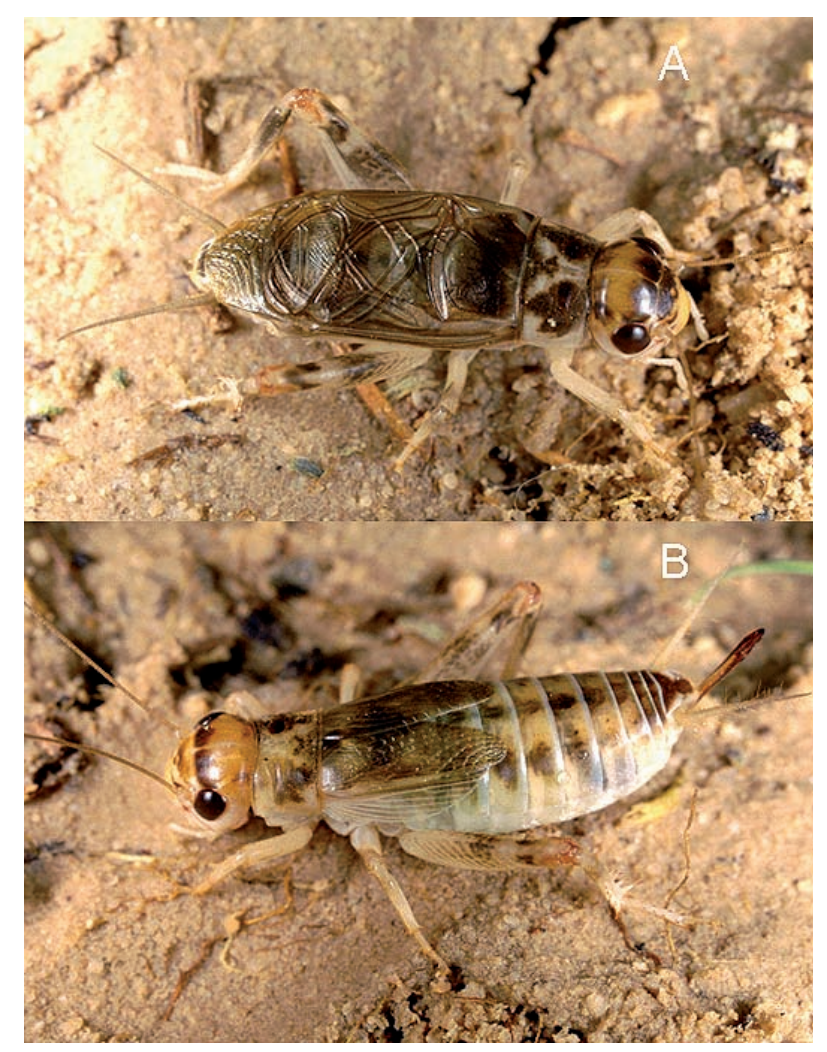

Fig. 1.- Gryllodinus kerkennensis from Villacañas, Toledo, Spain. A) male and B) female

Fig. 1.- Gryllodinus kerkennensis de Villacañas, Toledo, España. A) macho y B) hembra.

females (Uvarov, 1912). Without any doubt the most relevant character for recording this species is song.

\section{THE STUDY AREA}

Given the habitat preferences of this species for saline areas close to reservoirs of water in arid land (e.g. Gorochov \& Llorente 2001), we centered our research around hipersaline lagoons and brackish low land in localities of Toledo and Ciudad Real (Castilla-La Mancha, Central Spain) where the species was recorded in the past. The area is 500-650 $\mathrm{m}$ above-sea level and climate is mesoMediterranean, with mean temperatures ranging from $24-26^{\circ} \mathrm{C}$ in July to $4-6^{\circ} \mathrm{C}$ in January, and 300 $400 \mathrm{~mm}$ of rainfall mainly concentrated in spring and autumn, surrounded by extensively cultivated fields mainly of barley (Hordeum vulgare), wheat (Triticum spp.) and vineyards (Vitis vinifera). Other 
habitats include scattered olive groves (Olea europaea), some recent pine plantations (Pinus spp.) and non-cultivated areas covered with pastures.

We used twilight and mostly night listening points to identify presence/absence of G.k (also Fischer et al., 1997; Riede, 1998; Beggren et al., 2001). Listening points consisted of stations of 30 minutes in silence, listening and monitoring the possible song of this cricket. Because of the highly audible and repetitive trill uttered by different individuals in choruses, G.k could be heard from a reasonable distance of 200-300 $\mathrm{m}$ and was easily differentiated by the human ear from any other cricket species in the area once the song is assigned to the species. Night listening counts under appropriate time, date and weather conditions were positive in the lagoon where we knew of presence of $G . k$ by walk counts directed to other orthopteran species (Peñahueca). However, and unlike other diurnal orthoptera (Gardiner et al., 2005), day transects yielded very poor information on $G . k$ in those localised patches of Peñahueca where the species is common. So, we used recording songs by night listening points as the optional method to detect this cricket in other sites. Once the song was identified, we carefully searched for the crickets on the ground with flashlights in order to record their physical presence, microhabitat and behaviour whenever possible. A negative recording did not mean per sé absence as song also depended on date, hour and prevailing weather conditions (mostly rain and temperature). So, to minimize unpredictable factors that could locally inhibit song, masking the presence of new populations, we performed night listening points at other sites relatively close to Peñahueca on the same night, similar hour and weather than those carried out at this lagoon that was used as a positive control. We performed 20 night listening points between October 2006 and September 2008: 10 in "Peñahueca" (39 $31^{\circ} 12^{\prime}$ "N, $3^{\circ} 20^{\prime} 3$ "W) (Villacañas); one in "Tirez" (39 $32^{\circ}$ ' $22^{\prime \prime} \mathrm{N}, 3^{\circ} 21^{\prime} 13^{\prime \prime} \mathrm{W}$ ) (Villacañas); two in "La Grande" (39 30'10"N 3ำ'21'"W) (Quero); one in "El Salobral de Ocaña"("El Corralejo") (3959' 23 "N 3 37'07"'W) (Ocaña); one in "Lagunilla de la Sal" (39²6'16"N 3'19'50"W) (Villafranca de los Caballeros) from the province of Toledo. Three in "Salicor" (39²8'10"N 310’30"W) (Campo de Criptana) and two in "La Inesperada" (also "laguna del Prado") (3855'28”N 3\%49'50”W) (Pozuelo de Calatrava) in the province of Ciudad Real.

We used all museum specimens of the Museo Nacional de Ciencias Naturales of Madrid, Spain $(\mathrm{MNCN})$ and own captures (8 individuals) to provide a general picture of the phenology and body measurements of G.k. The measures taken were: Body size $=$ Distance between tip of head to distal extreme of the last terguite. Head = Width of the outer distance between the eyes. Pronotum length $=$ Maximum length between anterior and posterior margins of the pronotum. Pronotum width = Maximum width (posterior border). Tegmen $=$ Distance between pronotum edge to distal tip of tegmen. Femur $=$ Distance from proximal articulation of the posterior femur with abdomen (inferior view) to the knee (tibia articulation). Tibia $=$ Distance between posterior femur and tarsal articulations. Ovipositor $=$ Distance between distal edge of S8 and distal tip of ovipositor. All measures were taken with a flexible ruler to the nearest $0,5 \mathrm{~mm}$.

\section{Results}

The positive recordings with microhabitat and behavioural remarks for $G . k$ are the following: TOLEDO, Villacañas, "Peñahueca" lagoon: 2006/10/05, 15.00-20.00 h, 1 ㅇ nymph (last instar), over the shrub, no songs. 2007/03/13, 18.00-21.30 h, 1 o nymph (last instar) in a Suaeda vera prairie, hidden at the base of shrub; no songs. 2007/04/19, 19.00-23.00 h, high density of singing males (25 males in $200 \mathrm{~m}^{2}$ with several pregnant females) on the open and salty sand beach of the lagoon, below Suaeda vera shrubs; also three captures: $20^{7} 0^{7}$ and 1 ㅇ, (see Table 1). 2007/05/11, 10.00-15.00 h, a nymph $10 \mathrm{~mm}$ long under a rock close to a Microcnemum coralloides prairie; no songs. 2007/05/29, 03.45-04.15 h, choruses of singing males scattered along open areas close to water and humid sands. 2007/06/07, 23.00-23.30 h, males singing on sandy shores of the lagoon. 2007/06/27, 10.30-14.30 h, 1 O dead under a stone, close to a Microcnemum coralloides and Suaeda vera prairie; no songs. 2008/05/21, 21.00-23.00 h, choruses of males singing; males singing increasing in numbers, at first half hidden below Suaeda vera shrubs, becoming more and more visible in the open and along the shores of the lagoon as the night advances; also five captures: $30^{\top} 0^{7}$ and 2 우오. Villacañas, "Tirez" lagoon: 2007/05/28, 23.15-00.00 h, males singing in choruses by the shores of the lagoon. CIUDAD REAL, Pozuelo de Calatrava, "La Inesperada" lagoon: 2008/05/06, 21.30-23.30h, choruses of males singing. 2008/06/17, 21.00-23.50 h, choruses of males singing hidden in the sand and cracks of salted dried mud, amid prairies of Frankenia pulverulenta and Spergularia sp., also below large Suaeda vera shrubs; about 40 different singing points. 
Table 1.- G. $k$ specimens 1-36, from the MNCN collection and own recordings (37-44). I= Individuals: $5=$ Lectotype; $6=$ Paralectotype, both according to Gorochov \& Llorente (2001); 27= nymph in last instar; 31, 34, 35, 36= macropterous forms (parapterous). Locality/Source (label): 1= Río de Oro. Tachchent, Spanish Sahara (Western Sahara) (Morales-Agacino 1945); $2=$ Río de Oro. Ain Rag, Spanish Sahara, (Western Sahara) (Morales-Agacino 1947); 3= Pozuelo de Calatrava (Ciudad Real, Spain) (Fuente 1894); 4= Quero (Toledo, Spain); 5= Villacañas, (Toledo, Spain); 6= Ouargla, (Sahara) (Krauss 1902); 7= Biskra, (Algerie); 8= Ashchabad (Turkmenistan); 9=Zakaki meadows, (Cyprus); 10=Limassol Bay (sea shore, Cyprus); 11= Transcaspia; 12= This study, Villacañas, (Toledo, Spain). Collector/Ref: MA= Morales-Agacino; F= Fuente; JS= J. Sanz; CB= C. Bolívar; $\mathrm{GAM}=$ G.A.Mavromoustakis; $\mathrm{BA}=$ Biram-Ali; $\mathrm{S}=$ Soubowski; $\mathrm{K}=$ Krauss; PJC= PJ Cordero; PJC \& VL= P.J. Cordero \& V. Llorente; $\mathrm{UC}=$ Unknown collector. Totals represent mean $\pm \mathrm{SD}$ and range values. Total males include the subsample of Western Sahara, virtually the largest of all individuals measured. For averages of total females we excluded the nymph (specimen 27) and included all females both micropterous and macropterous (long hind wings) forms.

Tabla 1.- Especímenes de $G . k$ de la colección del MNCN (1-36) y registros propios (37-44,). I= Individuos: 5= Lectotipo; 6= Paralectotipo, ambos según Gorochov \& Llorente (2001); 27= ninfa en último estadio; 31, 34, 35, 36= formas macrópteras (parápteras). Localidad/Fuente (Etiqueta): 1= Río de Oro. Tachchent, Sahara Español (Sahara Occidental) (Morales-Agacino 1945); 2= Río de Oro. Ain Rag, Sahara Español (Sahara Occidental). (Morales-Agacino 1947); 3= Pozuelo de Calatrava (Ciudad Real, España) (Fuente 1894); 4= Quero (Toledo, España); 5= Villacañas, (Toledo, España); 6= Ouargla, (Sahara) (Krauss 1902); 7= Biskra, (Argelia); 8= Ashchabad (Turkmenistán); 9= Praderas de Zakaki, (Cyprus); 10=, Bahía de Limassol (orillas del mar, Cyprus); 11= Transcaspia; 12= Este estudio, Villacañas, (Toledo, España). Collector/Ref: MA= Morales-Agacino; F= Fuente; JS= J. Sanz; $\mathrm{CB}=\mathrm{C}$. Bolívar; GAM= G.A.Mavromoustakis; BA= Biram-Ali; $\mathrm{S}=$ Soubowski; K= Krauss; PJC= PJ Cordero; PJC \& $\mathrm{VL}=\mathrm{PJ}$ Cordero and V Llorente; $\mathrm{UC}=$ Colector desconocido. Los totales representan valores de medias \pm desviación standard $\mathrm{y}$ rangos. Machos totales incluye la submuestra del Sahara Occidental que son los más grandes de todos los individuos medidos. Para los promedios del total de hembras hemos excluidos la ninfa (espécimen 27) y hemos incluido todas las hembras tanto en su forma micróptera como macróptera (alas posteriores largas).

\begin{tabular}{|c|c|c|c|c|c|c|c|c|c|c|c|c|}
\hline I. & $\begin{array}{l}\text { Locality/ } \\
\text { Source }\end{array}$ & Date & $\begin{array}{l}\text { Collector/ } \\
\text { Ref }\end{array}$ & Sex & $\begin{array}{l}\text { Body } \\
\text { Size }\end{array}$ & Head & $\begin{array}{c}\text { Pronot. } \\
\text { Lengh }\end{array}$ & $\begin{array}{c}\text { Pronot. } \\
\text { Width }\end{array}$ & Tegmen & Femur & Tibia & Ovipositor \\
\hline 1 & 1 & $1943 / 03 / 23$ & MA & $0^{x}$ & 14,5 & 6,5 & 2,5 & 4,5 & 11,0 & 9,5 & 6,0 & - \\
\hline 2 & 2 & $1946 / 03 / 21$ & MA & $\sigma^{\pi}$ & 21,0 & 4,5 & 3,0 & 6,0 & 13,0 & 11,0 & 7,0 & - \\
\hline 3 & 2 & $1946 / 03 / 21$ & MA & $\sigma^{7}$ & 18,0 & 7,5 & 3,0 & 8,5 & 12,5 & 11,0 & 7,5 & - \\
\hline 4 & 2 & $1946 / 03 / 21$ & MA & $\sigma^{x}$ & 18,0 & 6,5 & 3,0 & 8,0 & 12,0 & 11,0 & 6,5 & - \\
\hline 5 & 3 & $1893 ?$ & $\mathrm{~F}$ & $\sigma^{\pi}$ & 13,0 & 4,0 & 2,0 & 4,5 & 10,5 & 8,0 & 5,0 & - \\
\hline 6 & 3 & $1893 ?$ & $\mathrm{~F}$ & 우 & 12,5 & 4,5 & 2,5 & 4,5 & 7,0 & 7,5 & 5,0 & 5,0 \\
\hline 7 & 4 & $1905 / 05 / 15$ & $\mathrm{UC}$ & 우 & 12,5 & 5,0 & 2,5 & 4,5 & 8,0 & 8,5 & 6,0 & 5,0 \\
\hline 8 & 4 & $1905 / 06 / 12$ & UC & $0^{x}$ & 13,0 & 4,5 & 2,5 & 4,5 & 10,5 & 8,0 & 5,0 & - \\
\hline 9 & 4 & $1905 / 05 / 15$ & UC & 우 & 12,0 & 5,0 & 2,5 & 4,5 & 6,5 & 8,5 & 5,5 & Broken \\
\hline 10 & 4 & $1905 / 05 / 15$ & UC & 우 & 10,0 & 4,5 & 2,5 & 4,5 & 7,0 & 8,0 & 5,5 & Broken \\
\hline 11 & 4 & $1905 / 05 / 15$ & UC & 우 & 16,0 & 4,5 & 2,5 & 4,5 & Broken & 8,5 & 5,5 & 5,5 \\
\hline 12 & 4 & $1905 / 05 / 15$ & UC & $0^{x}$ & 12,0 & 4,0 & 2,0 & 4,0 & 9,5 & 7,0 & 5,0 & - \\
\hline 13 & 4 & $1905 / 05 / 15$ & UC & $\sigma^{x}$ & 14,0 & 4,5 & 2,5 & 5,0 & 11,0 & 8,5 & 5,5 & - \\
\hline 14 & 4 & $1905 / 05 / 15$ & $\mathrm{UC}$ & $0^{x}$ & 13,0 & 4,5 & 2,0 & 4,5 & 11,0 & 8,5 & 5,5 & - \\
\hline 15 & 4 & $1905 / 06 / 12$ & UC & $0^{x}$ & 13,5 & 4,5 & 2,5 & 4,5 & 10,0 & 8,5 & 5,5 & - \\
\hline 16 & 4 & $1905 / 06 / 12$ & UC & $0^{x}$ & 12,5 & 4,0 & 2,0 & 4,0 & 11,5 & 8,0 & 5,0 & - \\
\hline 17 & 4 & $1905 / 05 / 15$ & UC & $\mathrm{f}$ & 13,0 & 4,5 & 2,5 & 4,5 & 6,5 & 8,0 & 5,5 & 5,0 \\
\hline 18 & 4 & $1905 / 05 / 15$ & UC & $0^{x}$ & 12,0 & 4,0 & 2,5 & 5,0 & Broken & 7,5 & 5,5 & - \\
\hline 19 & 4 & $1905 / 05 / 15$ & UC & 웅 & 13,0 & 4,5 & 2,5 & 4,5 & 8,0 & 8,5 & 5,5 & 5,0 \\
\hline 20 & 4 & $1908 / 05$ & JS & $0^{x}$ & 12,0 & 4,5 & 2,0 & 4,5 & 10,5 & 7,5 & 5,5 & - \\
\hline 21 & 4 & $1908 / 05$ & JS & $0^{x}$ & 13,0 & 4,5 & 2,0 & 4,5 & 11,5 & 8,5 & 5,5 & - \\
\hline 22 & 4 & $1908 / 05$ & JS & 우 & 14,0 & 4,5 & 2,5 & 4,5 & 7,5 & 8,5 & 5,5 & 5,5 \\
\hline 23 & 4 & No Date & $\mathrm{CB}$ & 우 & 14,5 & 4,5 & 2,5 & 4,0 & 6,5 & 8,5 & 5,5 & 5,0 \\
\hline 24 & 5 & $1934 / 05 / 21$ & $\mathrm{CB}$ & 우 & 13,0 & 4,5 & 2,5 & 4,0 & 6,5 & 8,5 & 5,5 & 5,0 \\
\hline 25 & 5 & $1934 / 05 / 21$ & $\mathrm{CB}$ & $0^{\pi}$ & 12,0 & 4,0 & 2,0 & 4,0 & 10,5 & 7,0 & 5,0 & \\
\hline 26 & 5 & $1934 / 05 / 21$ & $\mathrm{CB}$ & 우 & 14,0 & 4,5 & 2,5 & 4,0 & 7,5 & 8,5 & 5,0 & 5,0 \\
\hline 27 & 5 & $1934 / 05 / 21$ & $\mathrm{CB}$ & 우 & 12,0 & 4,0 & 2,0 & 3,5 & 4,0 & 7,0 & 4,5 & 3,0 \\
\hline 28 & 5 & $1936 / 06 / 00$ & MA & 우요 & 13,0 & 4,5 & 2,0 & 4,0 & 7,0 & 8,0 & 5,0 & 5,0 \\
\hline 29 & 6 & $1893 / 04 / 08$ & K & $\sigma^{7}$ & 14,0 & Broken & 2,0 & 4,5 & 10,5 & 8,5 & 5,5 & - \\
\hline
\end{tabular}


Table 1.-(Cont.).

\begin{tabular}{|c|c|c|c|c|c|c|c|c|c|c|c|c|}
\hline I. & $\begin{array}{l}\text { Locality/ } \\
\text { Source }\end{array}$ & Date & $\begin{array}{l}\text { Collector/ } \\
\text { Ref }\end{array}$ & Sex & $\begin{array}{l}\text { Body } \\
\text { Size }\end{array}$ & Head & $\begin{array}{l}\text { Pronot. } \\
\text { Lengh }\end{array}$ & $\begin{array}{c}\text { Pronot. } \\
\text { Width }\end{array}$ & Tegmen & Femur & Tibia & Ovipositor \\
\hline 30 & 7 & No Date & UC & ㅇ & Broken & 4,5 & 2,5 & 4,5 & 7,0 & 9,0 & 5,0 & 4,5 \\
\hline 31 & 8 & No Date & $\mathrm{S}$ & 우 & 15,0 & 4,5 & 2,0 & 4,0 & 11,0 & 8,0 & 5,5 & 5,5 \\
\hline 32 & 9 & $1925 / 05 / 20$ & GAM & $\sigma^{x}$ & 11,0 & 4,5 & 2,0 & 4,5 & 10,0 & 7,5 & 4,5 & - \\
\hline 33 & 10 & $1925 / 05 / 22$ & GAM & $0^{x}$ & 13,0 & 4,5 & 2,0 & 4,5 & 10,5 & 8,0 & 5,0 & - \\
\hline 34 & 11 & $1923 / 06 / 04$ & $\mathrm{BA}$ & 우 & 18,0 & 4,5 & 2,5 & 4,5 & 9,5 & 8,5 & 6,0 & 5,5 \\
\hline 35 & 11 & $1922 / 05 / 01$ & BA & $\sigma^{7}$ & Broken & 4,5 & 2,0 & 4,5 & 11,0 & 8,0 & 5,0 & - \\
\hline 36 & 11 & No Date & $\mathrm{S}$ & 우 & 15,5 & 4,5 & 2,5 & 4,0 & 10,0 & 8,0 & 5,0 & 5,0 \\
\hline 37 & 12 & $2007 / 04 / 19$ & PJC & $\sigma^{7}$ & 15.0 & 4.5 & 3.0 & 5.0 & 10.0 & 8.0 & 5.0 & - \\
\hline 38 & 12 & $2007 / 04 / 19$ & PJC & $\sigma^{2}$ & 15.0 & 4.5 & 3.0 & 5.0 & 11.5 & 8.5 & 5.5 & - \\
\hline 39 & 12 & $2007 / 04 / 19$ & PJC & 우 & 18.0 & 4.5 & 3.0 & 4.5 & 6.5 & 8.5 & 5.0 & 5.0 \\
\hline 40 & 12 & $2008 / 05 / 21$ & PJC \& VL & ○ & 18.0 & 4.5 & 3.0 & 4.0 & 7.5 & 8.5 & 5.5 & 5.0 \\
\hline 41 & 12 & $2008 / 05 / 21$ & PJC \& VL & 우 & 14.5 & 4.5 & 2.5 & 4.0 & 7.5 & 8.5 & 5.0 & 5.5 \\
\hline 42 & 12 & $2008 / 05 / 21$ & PJC \& VL & $\sigma^{7}$ & 13.0 & 4.0 & 2.5 & 4.0 & 11.5 & 8.5 & 5.0 & - \\
\hline 43 & 12 & $2008 / 05 / 21$ & PJC \& VL & $\sigma^{7}$ & 12.5 & 4.5 & 2.5 & 4.5 & 11.5 & 8.5 & 5.5 & - \\
\hline 44 & 12 & $2008 / 05 / 21$ & PJC \& VL & $\sigma^{2}$ & 13.0 & 4.5 & 2.5 & 5.0 & 12.0 & 8.5 & 5.5 & - \\
\hline \multicolumn{5}{|c|}{ TOTAL } & $13.83 \pm 2.33$ & $4,67 \pm 0.90$ & $2,37 \pm 0,40$ & $4,85 \pm 1,13$ & $11.02 \pm 0.86$ & $8.48 \pm 1.12$ & $5.48 \pm 0.68$ & \\
\hline \multicolumn{5}{|c|}{ MALES } & $11.00-21.00$ & $4.00-7.50$ & $2,00-3,00$ & $4,00-8,50$ & $9.50-13.00$ & $7.00-11.00$ & $4.50-7.50$ & \\
\hline \multicolumn{5}{|c|}{ TOTAL } & $14,13 \pm 2,21$ & $4,52 \pm 0,20$ & $2,47 \pm 0,25$ & $4,25 \pm 0,30$ & $7,42 \pm 1,51$ & $8,27 \pm 0,44$ & $5,32 \pm 0,37$ & $5,00 \pm 0,37$ \\
\hline \multicolumn{5}{|c|}{ FEMALES } & $10,00-18,00$ & $4,50-5,00$ & $2,00-3,00$ & $4,00-4,50$ & $6,50-11,00$ & $7,50-9,00$ & $5,00-6,00$ & $4,50-5,50$ \\
\hline
\end{tabular}

Listening points with no song recorded were: TOLEDO, Villacañas, "Peñahueca" lagoon: 2006/10/05, 21,00-22,00 h; 2006/10/26, 20,00-21,00 h; 2007/02/27, 20,00-21,00 h; 2007/11/02, 15,0021,00 h. Quero, "La Grande": 2007/06/07, 22.3023.00 h. 2008/05/27, 22.30-23.00 h Ocaña, "Salobral de Ocaña": 2008/05/21, 00.00-01.00 h. Villafranca de los Caballeros, "Lagunilla de la Sal": 2008/05/27, 20.00-22.00 h. CIUDAD REAL, Campo de Criptana, "Salicor" lagoon: 2007/05/28, 22,00-23,00 h.; 2007/06/07, 22.00-22.15 h; 2008/09/01, 21-21.45 h.

Our recordings indicate that $G . k$ is present at least in "Peñahueca" and "Tirez", (2 km apart) within the district of Villacañas (Toledo), and in "La Inesperada", district of Pozuelo de Calatrava (Ciudad Real, $89 \mathrm{~km}$ SW from Peñahueca). We understand that negative records for Peñahueca in February, March, October and November indicate no sexual activity or the lack of adults. However, no song recordings in April, May and June in La Grande (Quero, 7,2 km E), El Salobral de Ocaña (Ocaña, 55 $\mathrm{km} \mathrm{N}$ ), Salicor (Campo de Criptana, $15 \mathrm{~km} \mathrm{SE}$ ) or Lagunilla de la Sal (Villafranca de los Caballeros, 8 $\mathrm{km} \mathrm{S}$ ) suggest the absence of the species.

$G . k$ sings in salty sand in the proximity of the shores of hiper-saline lagoons and excavates gal- leries with openings under small rocks, below small Suaeda vera shrubs or prairies of Frankenia pulverulenta and Spergularia sp. The species occurs in patches with relatively dense aggregations in certain areas of the lagoons. It is rarely seen during the day, coming out in the late afternoon and at sunset when they are usually found outdoors, climbing up Suaeda vera shrubs. Song starts at sunset and lasts throughout the night between April and June. Males sing in very noisy and crowded choruses in which they may be toned differentially and individually. Choruses may gather up to 25 males in a short space of $200 \mathrm{~m}^{2}$ which may come together in a sort of arena. Song usually occurs close to the shores of the lagoons on open grounds where females are also present but in much smaller densities. Nymphs in last instar are seen in October and March suggesting that they may over-winter in this stage becoming adults in late March and reproducing in early April, May and probably June. Pregnant females are seen in mid April. Nymphs of $10 \mathrm{~mm}$ length are detected by the second week of May suggesting that the first hatchlings may appear immediately after the egg-laying of April. We did not find adults beyond the end of June. Song or adults observations are lacking in autumn suggesting a univoltine nature in this cricket. 
Measurements of specimens collected (37-44) and those kept in the MNCN from different regions and measured by the authors (1-36) are given in Table 1. In general, the description of our specimens collected or those inspected by us in the field matched with most individual populations identified by other authors. However, we did not record macropterous forms like those of the Transcaspian area. We notice the apparent larger size of individuals from the Western Sahara (Student $\mathrm{T}$ tests for all measurements, $\mathrm{P} \leq 0.003$ ) (Table 1 ).

\section{Discussion}

G.k is present at least at three hiper-saline lagoons of two localities where the species was formerly recorded in Spain from 1894 until 1936, inhabiting salty sands and dried muds around these lagoons in the halophile vegetation rings where the main shrubs are Suaeda vera, Frankenia pulverulenta or Spergularia sp. Thus, the habitat where we have found it has components already mentioned by other authors as salinity and humidity (Gangwere and Morales-Agacino, 1970) or salinity in the proximity of water reservoirs (Gorochov \& Llorente, 2001). Uvarov (1912) mentions this cricket in arid, semi-desert or desert land, but only on saline low grounds covered by small shrubs like Limonium $s p$. and other halophile plants in the depression between the Kuma and Manych rivers in the region of Stavropol (European part of the Russian Federation). In turn, Semenov (1915) found it in the same region far from saline low land, on the clay walls of an old fortress where they hid in the crevicies of the ruins. Chopard (1943) cites this cricket from desert land even in areas almost bare of vegetation and in the salty sand along the shores of the "sebkhas", a sort of depression of lime and salt in some desert zones of North Africa where they hide during the day buried in the sand. Morales-Agacino (1945) observed this cricket in the Western Sahara on low land covered with halophiles like Tamarix sp. or with Nitraria retusa and Aizoon theurkaufii (Morales-Agacino, 1947). The species has also been found on sandy beaches at the sea shores of Cyprus (MNCN collection, see Table 1). In the Transcaspian area, this cricket has been recorded in arid, semi-desert or desert land (Uvarov, 1912; Semenov, 1915; Fernandes, 1967). It seems clear that $G . k$ requires arid land either with sandy grounds or multiple crevices as those provided by old ruined buildings where they shelter from predators and inclement weather.
We do not know with certainty if the restricted habitat and reduced distribution found for $G . k$ is relict of what it was in the Iberian Peninsula at the end of the nineteen century when the earliest Spanish entomological studies were carried out (Fuente, 1894; Bolívar, 1894), or if its distribution was like it is now. By its peculiar song, the cricket is expected to be detectable easily wherever present (e.g. Semenov, 1915; this study), however the scarce information available on the species is striking except if we assume a very localised distribution limited to a few hipersaline lagoons of Castilla-La Mancha. This extreme fragmentation of $G . k$ populations in Central Spain could be related to possible successive local extinctions along time. Negative listening points in "La Grande" (Quero), "Salicor" (Campo de Criptana) and "La Lagunilla de la Sal" (Villafranca de los Caballeros) indicate that the species is absent there. In fact, one of the difficulties to evaluate possible differences in population size in relation to the past is that old Spanish records lack a description of the habitat and sites where the specimens were collected (Fuente, 1894; Fernandes, 1967). If we assume that the individuals were collected in saline habitats, as we did in Villacañas and Pozuelo de Calatrava, we could suggest that the species disappeared from Quero as the night listening points were negative. Also, we have investigated the archives of the Museo Provincial of Ciudad Real, where all the unpublished work by Fuente is deposited. Unfortunately we did not obtain any clue about the precise place where he could have found this cricket in Pozuelo de Calatrava. We suspect that it was in "La Inesperada" a hiper-saline lagoon that has suffered different habitat changes since Fuente published his work in 1894. This lagoon was first used as a rubbish dump and more recently cleaned and recovered as a bird refuge in which the water regime has been altered with treated sewage waters. Consequently, the shores of this lagoon are now different to any other hiper-saline lagoon in the area but the species is living there in spite of human intervention. Also, in the enquiries made we have obtained some indirect evidence that the species could have been present a few years ago in "Salicor". Professional keepers of these natural reserves patrolling the area reported to us a particular cricket song in "Salicor" identical to that of "Peñahueca" with characteristics of those of $G . k$ (Carlos Torralbo, pers. com.).

Our phenology scheme for the Spanish G.k population found is totally in accordance with observations provided in the literature (Uvarov, 1912; 
Semenov, 1915; Fernandes, 1967; Gorochov \& Llorente, 2001). In all other areas of distribution, adults have been recorded from late March like in the Western Sahara (Morales-Agacino, 1945, 1947) and Kuwait (Gorochov, 1993); during April as in Transcaspia (Uvarov, 1912; Semenov, 1915) and Afghanistan (Chopard, 1960); May in Transcaspia (Uvarov, 1912; Semenov, 1915), Near East (Fernandes, 1967) with last observations in early July (Uvarov, 1912) reinforcing our observations on adult activities and phenology (see also Table 1). Morales-Agacino (1947) cited that males sang only during short periods between 21 and $22 \mathrm{~h}$ in late March. This may be true when air temperature may drop below a certain value as the night progresses; however this is not the case in late May when singing may be heard all night through (this study). In fact, observations of laboratory kept individuals show that males sing all night and at dawn; sometimes late in the afternoon before sunset, but song deteriorates by the end of June and indivuals die shortly afterwards. We have recorded last instar nymphs in autumn and in early spring indicating that nymphs stop growing and over-winter in a lethargy state, that we have assessed with laboratory kept individuals. We have recorded first instar of nymphs in April, suggesting the univoltine nature of this cricket. However, we cannot discard that those individuals born in early spring could be reproducing as early as June as suggested by a last instar nymph specimen from the collection of the MNCN with label: Villacañas, C.Bolívar, 1934 May $21^{\text {st }}$ (specimen 27 in Table 1).

Although sample sizes are small, specimens of $G . k$ found do not differ in measurements from other individuals collected in the area and its sorroundings more than a hundred years ago. In fact almost all individuals measured and deposited in the MNCN are virtually similar in size with the notable exception of those collected from the Western Sahara by Morales-Agacino which are significantly larger in all measurements taken (Table 1). Also, we only detected micropterous forms whereas in the MNCN collection some macropterous forms are all from the Transcaspian area. It is probable that variation in size and length of posterior wings was a trait common to different populations of the species like those in body size of the Western Sahara population (specimens 1-4 of Table 1) or those between Stavropol and Transcaspia (Semenov, 1915).

\section{THREATS AND CONSERVATION STATUS}

The species remains confined to halophile vegetation rings in hiper-saline lagoons of arid land.
Agricultural activities and shepherding are human modelling agents reducing the extension of these vegetation rings, reducing communities of plants of saline environments, increasing fragmentation and erecting barriers to the expansion of this cricket. Though some of these places enjoy government protection and the halophile plant communities are also globally protected under European and Regional legislations (Martín-Herrero et al., 2003), the fragility of these highly vulnerable habitats is permanent because of their isolation, fragmentation and uncontrolled human intervention. Spillage of residual waters, deposits of solid wastes and other punctual human aggressions may also affect these singular environments and thus the surviving of this and many other singular species of halophile or halophile resistant plants and macro-invertebrates. Furthermore, new or additional perils threaten the survival of this cricket populations found. These threats are related with priorities for plan management actions enhancing bird conservation over other taxa: projects for increasing water regime with treated sewage waters. This sort of project is a real risk for local extinction in " $\mathrm{La}$ Inesperada". In this hipersaline lagoon where G.k maintains a small and isolated population, a higher increase in water levels, aimed at enhancing waterfowl and other aquatic bird populations, would be incompatible with the persistence of this cricket, as the halophile vegetation ring has been reduced by human intervention. Furthermore, water and large migratory birds are using more and more the hipersaline lagoons as resting, feeding or breeding sites. Large amounts of birds in small, isolated and singular habitats may negatively affect the composition of soils and the halophile plant communities with droppings and other activities in search of food, direct predation included, thus generating a compromise of conservation between taxa. Additionally, atmospheric catastrophes may also affect negatively the hipersaline habitats of $G . k$ and thus its populations. For example, the effects of flash flooding are parallel to those of artificially increasing water levels and may reduce or eliminate different species of halophile macro-invertebrates. An intense flash flooding event has occurred recently in "La Grande" (Quero) and "Salicor" (Campo de Criptana) occasioning a dramatic reduction in other halophile or halophile resistant orthopteran populations (P.J. Cordero et al., in prep.).

Because of the local distribution and the extraordinary fragility of its habitat, we believe that our population of $G . k$ is submitted to an extremely high risk of extinction. The difficulty of dispersion in this species whose habitat is severely isolated by 
plowed cultivated land and roads hampered even more the probability of re-colonisation of new areas where it could have gone extinct recently. However, the rediscovery of this species for the Spanish fauna in this study opens the possibility of taking measures of total protection of the species and areas which it inhabits and raises the need to categorize the species as severely endangered and include it among the highest priorities for species conservation schedules.

Apart from the plain interest of conservation of this severely endangered species in Western Europe, G.k has an added value per se as it is an important component of the arid land and hipersaline lagoons landscapes: This is because of its particular song, extremely melodious among any other insect in our latitudes (see also Semenov, 1915) and which can be heard during twilight and at night. Because of this attractive song, similar to a silver bell continuously ringing (Semenov, 1915; Morales-Agacino, 1945), we name this cricket the "silver-bell cricket" assuming that common names stimulate the interest of the many people who may participate in practical conservation (New, 2008).

In conclusion, we have found small, but dense and localised, populations of $G . k$ in Castilla-La Mancha (Spain) that require urgent attention and protection before adverse environmental stochasticity. Given that this cricket has been found only in singular and vulnerable habitats, its conservation status should be revised. We also outline the need for investigating the possible presence of this species in other similar habitats throughout the Iberian Peninsula, for example following Mioscirtus wagneri distribution, as both species share similar saline environments (Fernandes, 1967). To attain this, we propose night listening points between the end of March and June, preferably in late April and in May as this is the easiest way to reveal the presence of $G . k$ populations since song is predictable and highly audible even from a certain distance. Also, and simultaneously, we propose the integral and strict protection for the silver-bell cricket and its habitats and the need of its inclusion in the Spanish red list of the invertebrate fauna.

\section{ACKNOWLEDGEMENTS}

This study has been funded thanks to projects: PAI-05-053 and PCI08-0130 from La Junta de Comunidades de Castilla-La Mancha (JCCLM) and project CGL2005-05611-C02-02/BOS from the Ministerio de Educación y Ciencia. We thank Juan José Presa and also Felipe Pascual who improved an early version of this manuscript. Santos Cirujano resolved some ques- tions on plants identification. Carlos Torralbo helped us with information from Salicor (Campo de Criptana) and Jesús Muñoz kindly gave us access to the Inesperada (Pozuelo de Calatrava). Most of the lagoons in this study are currently Natural Reserves of the JCCM. This study was carried out under license of the JCCM.

\section{References}

Berggren, A., Carlson, A \& Kindvall, O., 2001. Introduced Bush-Crickets Metrioptera roeseli. Journal of Animal Ecology, 70: 663-670.

BOLÍVAR, I., 1894. Cognitionem Orthopterorum Europae et confinium sobre el género Gryllodes Saussure. Actas Sociedad Española Historia Natural, 23: 44-58.

Bolívar, I., 1898. Catálogo sinóptico de los ortópteros de la fauna ibérica ( $3^{\mathrm{a}}$ parte) Annaes des Sciencias. Naturaes, (Porto), 5: 1-48.

Bolívar, I., 1927. Datos complementarios sobre los Ortópteros de la Península Ibérica. Boletín de la Real Sociedad Española de Historia Natural, 27: 96-110.

CHOPARD, L., 1927. Description of a cricket supposed to present Termitophilous habits. Annals and Magazine of Natural History, Serie 9, 19: 255-258.

ChOPARD, L., 1943. Faune de l'Empire française. I. Orthoptéroïdes de l'Afrique du Nord. Larose. Paris. $450 \mathrm{pp}$.

ChOPARD, L., 1960. Contribution à l'etude de la faune d'Afghanistan, 35 Gryllides. Eos, 36: 389-401.

Cordero, P. J., Llorente, V. \& Aparicio, J. M., 2007a. New data on morphometrics, distribution and ecology of Mioscirtus wagneri (Kittary, 1849) (Orthoptera, Acrididae) in Spain: Is maghrebi a well defined subspecies? Graellsia, 63(1): 3-16.

Cordero, P. J., Llorente, V. \& Aparicio, J. M., $2007 \mathrm{~b}$. A new cricket (Orthoptera, Gryllidae) for Castilla-La Mancha and the Iberian Peninsula. Graellsia, 63(2): 305-313.

FERNANDES, J. A., 1967. Les Gryllides de la faune ibérique. I-Les genres Gryllodinus Bol. et Eugryllodes Chop. Révisión critique. Arquivos do Museu Bocage, 1(17): 351-391

FinOT, A., 1893. Huit espèces nouvelles d'Orthoptères. Annales de la Société Entomologique de France, Bulletin, 62: 250-253.

Fischer, F. P., Schulz, U., Schubert, H., Knapp, P. \& SCHMÖGER, M., 1997. Quantitative assessment of grassland quality: acoustic determination of population sizes of orthopteran indicator species. Ecological Applications, 7: 909-920.

Fuente, J. M., 1894. Dos nuevos ortópteros de España. Actas de la Sociedad Española Historia Natural, 22: 137. 
Gangwere, S.K, De Viedma, M. G. \& Llorente, V., 1985. Libro rojo de los ortópteros ibéricos. Ministerio de Agricultura, Pesca y Alimentación. Monografías ICONA, 41. Madrid. 91pp.

Gangwere, S.K. \& Morales-Agacino, E., 1970. The biogeography of Iberian Othopteroids. Miscel-lànea. Zoológica, 2(5): 9-75.

Gardiner, T., Hill, J. \& Chesmore, D., 2005. Review of the methods frequently used to estimate the abundance of Orthoptera in grassland ecosystems. Journal of Insect Conservation, 9: 151-173.

Gorochov, A. V., 1979. Crickets (Orhtoptera, Gryllidae) of Soviet Central Asia. Entomological Review, 58: 44-48.

Gorochov, A. V., 1993. Grylloidea (Orthoptera) of Saudi Arabia and adjacent countries. Fauna of Saudi Arabia, 13: 79-97.

Gorochov, A. V. \& Llorente, V., 2001. Estudio taxonómico preliminar de los Grylloidea de España (Insecta, Orthoptera). Graellsia, 57: 95-139.

Harz, K. 1969. Die Orthopteren Europas. I. W. Junk, Series Entomologica, 5. The Hague. 749 pp.

Martín-Herrero, J., Cirujano-Bracamonte, S., MorenoPérez, M., Peris-Gisbert, J. B. \& StüBing-Martínez, G., 2003. La vegetación protegida en Castilla-La Mancha. JCCM - CSIC. Madrid. 375 pp.

Morales-Agacino, E., 1945. Algunos datos sobre Ortopteroides del Sáhara Occidental. Eos, 20: 309339.

Morales-Agacino, E., 1947. Notas sobre Ortopteroides de Ifni y Sáhara Español. Eos, 23: 241-283.

NEW, T. R., 2008. What's in common names: are they really valuable in insects conservation? Journal of Insects Conservation, 12: 447-449.

Popov, A. V. \& Shuvalov, V. F., 1977. Phonotactic behaviour of crickets. Journal of Comparative Physiology, 119: 111-126.

RANDELL, R. L., 1964. The male genitalia in Gryllinae (Orthoptera: Gryllidae) and a tribal revision. The Canadian Entomologist, 96: 1565-1607.
RidLEY, K., 1998. Acoustic monitoring of Orthoptera and its potential for conservation. Journal of Insects Conservation, 2: 217-223.

Semenov, A., 1915. [Orthoptera. Uvarov's reviews of Ueber die Orthopterenfauna Transcaspiens. Horae Societatis Entomologicae Rossicae, 40: 37-51 (1912) and Aperçu de la faune des Orthoptères du government de Stavropol. Bulletin du Musée du Caucase, 9: 77-110 (1915).] Revue Russe d'Entomologie, 15: 449-457 (In Russian).

Uvarov, B. P., 1912. Ueber die Orthopterenfauna Transcaspiens. Horae Societatis Entomologicae Rossicae, 40: $37-51$.

Uvarov, B. P., 1943. Orthoptera of the Siwa Oases. Proceedings of the Linnean Society, London, 155: 821.

Verdú J. R. \& GALANTE, E., eds. 2005. Libro Rojo de los Invertebrados de España. Dirección General de Conservación de la Naturaleza, Madrid (versión online: http://carn.ua.es/CIBIO/es/lrie/lrie.html).
Recibido, 4-II-2008 Aceptado, 7-XI-2008 Publicado, 29-XII-2008 